\title{
Mantle cell lymphoma with features of marginal-zone lymphoma
}

\author{
Ulla Randen • Olav Erich Yri • Anne Tierens • \\ Sverre Heim • Klaus Beiske • Jan Delabie
}

Received: 26 January 2011 / Accepted: 7 February 2011 /Published online: 2 March 2011

(C) Springer-Verlag 2011

\begin{abstract}
We present seven cases of mantle cell lymphoma with morphological features of marginal-zone lymphoma. Of particular interest, four of the patients had predominant involvement of the gastrointestinal tract. All cases displayed the translocation $\mathrm{t}(11 ; 14)(\mathrm{q} 13 ; \mathrm{q} 32)$ and expressed cyclin D1. Cytogenetic analysis revealed trisomy 3 in one case and somatic hypermutation of immunoglobulin heavy genes could be demonstrated in two out of four cases. The latter features are reminiscent of marginal-zone lymphoma. The localization of these lymphomas mainly in the gastrointestinal tract and the higher exposure to antigens in this area may explain why this variant of mantle cell lymphoma harbours features of marginal-zone lymphoma.
\end{abstract}

U. Randen $(\bowtie) \cdot$ A. Tierens $\cdot$ J. Delabie

Department of Pathology, The Norwegian Radium Hospital,

Oslo University Hospital,

0310 Oslo, Norway

e-mail: ulla.randen@oslo-universitetssykehus.no

O. E. Yri

Department of Oncology, The Norwegian Radium Hospital, Oslo University Hospital,

Oslo, Norway

\section{S. Heim}

Section for Cancer Cytogenetics, Institute for Medical Informatics, The Norwegian Radium Hospital, Oslo University Hospital and University of Oslo,

Oslo, Norway

\section{K. Beiske}

Department of Pathology, The National Hospital,

Oslo University Hospital,

Oslo, Norway
Keywords Mantle cell lymphoma $\cdot$ Marginal-zone lymphoma $\cdot$ GI tract $\cdot$ Cyclin D1

\section{Introduction}

Mantle cell lymphomas are characterized by a vaguely nodular or diffuse proliferation of small to medium-sized cells with irregular nuclei. In some cases, reactive follicles are still present and surrounded by a neoplastic expanded mantle zone. The tumour cells express pan B-cell markers and usually CD5. Typically, an aberrant expression of cyclin D1 is demonstrated due to the translocation $\mathrm{t}(11 ; 14)$ (q13;q32). Mantle cell lymphoma comprises approximately $5-10 \%$ of non-Hodgkin lymphomas. The median survival time of mantle cell lymphoma is $3-5$ years, and most of the patients experience recurrence of their disease [1]. However, dose-intensified chemotherapy could potentially alter the prognosis for mantle cell lymphoma $[2,3]$.

Morphological variants of mantle cell lymphoma mimicking other B-cell non-Hodgkin lymphomas are rare. Previously, a total of 15 cases of a mantle cell lymphoma variant, mimicking marginal-zone lymphoma, have been reported [4-8]. We report here the clinical and pathology findings of an additional seven patients with this variant of mantle cell lymphoma.

\section{Materials and methods}

We have identified seven cases of mantle cell lymphomas with features of marginal-zone lymphoma in the archives of our department of pathology. Four of the patients were male and three were female, with an age range between 61 and 86 (median 74) years. They all presented with stage IV 
disease and four of seven patients showed predominant involvement of the gastrointestinal (GI) tract. The clinical data are summarised in Table 1.

\section{Immunohistochemistry}

Four-micrometer paraffin-embedded and formalin-fixed tissue sections were used for immunohistochemical staining. The primary antibodies used for immunophenotypic analysis of the lymphomas were: anti-CD45, antiCD20, anti-Bcl6, anti-Mum1, anti-IgA, anti-IgD, anti-IgG, anti-IgM, anti-Ki67 (all from Dako, Glostrup, Denmark), anti-CD10, anti-Bc12, anti-CD21, anti-CD23, anti-CD5, anti-CD43, anti- cyclin D1 (all from Novocastra Laboratories, Newcastle upon Tyne, U.K.), anti-PAX5 (BD Biosciences, San José, CA) and anti-CD3 (Thermo Fisher Scientific, Fremont, CA). For all antibodies, heat-induced epitope retrieval was performed in a microwave oven by heating the slides for $5 \mathrm{~min}$ at $750 \mathrm{~W}$ and subsequently for $15 \mathrm{~min}$ at $500 \mathrm{~W}$ in retrieval buffer. The detection system Envision (Dako) was used for all antibodies. The stain was developed with 3,3'-diaminobenzidine and $\mathrm{H}_{2} \mathrm{O}_{2}$, and the slides were counterstained with haematoxylin. The immunostaining was performed in a Dako Autostainer (Dako) according to the instructions of the manufacturer.

Flow cytometry

For samples of patients 1, 2, 5 and 6, four-colour flow cytometry analysis was performed on either peripheral blood, bone marrow or lymph node fine-needle aspirates anticoagulated with heparin. Between 0.5 and $1 \times 10^{6}$ cells were stained for surface antigens with the following antibody combinations labelled with fluorescein isothyocyanate/peridinin chlorophyll-cyanine 5.5/allophycocyanine: (1) CD20/CD5/CD19/CD43; (2) FMC7/CD23/ CD19/CD5; (3) $\operatorname{Ig} / / \operatorname{Ig} \lambda / C D 20 / C D 19 ;$ (4) CD22/CD24/ CD19/CD34; (5) cyBc12/CD10/CD19/CD38. All antibodies were purchased from Becton-Dickinson, San Jose, CA, U. S.A, except anti-FMC7 and anti-Bcl2, which were purchased from Dako. Flow cytometry analysis was performed on a FACSCalibur instrument (Becton-Dickinson) using BD Cell Quest Pro software (Becton-Dickinson).

Fluorescence in situ hybridization (FISH)

For fluorescence in situ hybridization (FISH) analysis, 2-2.5 $\mu$-thick paraffin-embedded tissue sections were cut, deparaffinized and pretreated using the Histology FISH Accessory Kit (Dako) according to the supplier's instructions. Sections were hybridised with the LSI IGH/CCND1 dual-colour, dual-fusion DNA probes (32-191017) for demonstration of the $\mathrm{t}(11 ; 14)(\mathrm{q} 13 ; \mathrm{q} 32)$ and the CEP 3 Spectrum Orange probe (32-130003) for demonstrating chromosome 3 ploidy. Both probes were purchased from Abbott Molecular Inc. (Des Plaines, IL, USA). Nuclei were counterhybridized with Dapi (Vector Laboratories Inc., Burlingame, CA, USA) and results were analysed with a Zeiss fluorescence microscope (Carl Zeiss MicroImaging Inc., New York, NY, USA). For each sample, 150-300 nuclei were evaluated. For slides hybridised with the IGH/CCND1 probe set, the percentage of nuclei containing at least one fused signal pair per nucleus was calculated. A ratio in excess of 2 for the number of CEP 3 signals per nucleus was interpreted as proof for trisomy 3 .

Table 1 Clinical data

\begin{tabular}{|c|c|c|c|c|c|}
\hline Pts & Sex/age (year) & Sites of involvement & Stage & Treatment & Outcome \\
\hline 1 & $\mathrm{~F} / 61$ & $\begin{array}{l}\text { Spleen, bone marrow } \\
\text { and blood }\end{array}$ & 4 & $\begin{array}{l}\text { Splenectomy. Rituximab and interferon } \alpha \text {; later treated in analogue } \\
\text { to the } 3 \text { rd Nordic MCL-protocol }{ }^{\mathrm{a}} \text {, with partial response, } \\
\text { thereafter rituximab maintenance therapy every } 3 \text { months }\end{array}$ & $\mathrm{CR}$ \\
\hline 2 & $\mathrm{M} / 61$ & $\begin{array}{l}\text { Lymph nodes, bone } \\
\text { marrow and duodenum }\end{array}$ & 4 & $\begin{array}{l}6 \times \text { Maxi-CHOP }^{\mathrm{b}}, \text { thereafter rituximab maintenance therapy } \\
\text { every } 3 \text { months }\end{array}$ & $\mathrm{CR}$ \\
\hline 3 & $\mathrm{M} / 82$ & $\begin{array}{l}\text { Lymph nodes, bone } \\
\text { marrow and stomach }\end{array}$ & 4 & Died before the start of treatment & Died with disease \\
\hline 4 & $\mathrm{~F} / 80$ & Rectum, bone marrow & 4 & Chlorambucil & PR, died of sepsis \\
\hline 5 & $\mathrm{~F} / 65$ & Lymph nodes & 4 & According to the 3 rd Nordic MCL protocol ${ }^{\mathrm{a}}$ & $\mathrm{CR}$ \\
\hline 6 & $\mathrm{M} / 84$ & Bone marrow & 4 & None & Died with disease \\
\hline 7 & $\mathrm{M} / 85$ & Colon, bone marrow & 4 & Reduced CHOP-treatment & Died with disease \\
\hline
\end{tabular}

a third Nordic MCL-protocol: alternating cytarabine $3 \mathrm{~g} / \mathrm{m}^{2}$ every $12 \mathrm{~h}$ for a total of four doses $\left(2 \mathrm{~g} / \mathrm{m}^{2}\right.$ for patients over 60$)+\mathrm{rituximab} 375 \mathrm{mg} / \mathrm{m}^{2}$ and maxi-CHOP ${ }^{\mathrm{b}}+$ rituximab; three courses of each, followed by high-dose therapy with autologous stem cell support (karmustin $300 \mathrm{mg} / \mathrm{m}^{2}$ day 1 , etoposide $300 \mathrm{mg} / \mathrm{m}^{2}$ days $1-4$, cytarabine $400 \mathrm{mg} / \mathrm{m}^{2}$ days $1-4$ and melfalan $140 \mathrm{mg} / \mathrm{m}^{2}$ day 5)

${ }^{\mathrm{b}}$ Maxi-CHOP: (cyclophosphamide $1,200 \mathrm{mg} / \mathrm{m}^{2}$, doxorubicin $75 \mathrm{mg} / \mathrm{m}^{2}$, vincristin $2 \mathrm{mg} / \mathrm{m}^{2}$ (all day 1) prednisolon $50 \mathrm{mg}$ tablet $\times 2$ per day, days $1-5$ ) + rituximab; totally six courses 


\section{G-banding analysis and karyotyping}

Fresh tissue samples were manually minced and enzymatically treated until a suitable suspension of cells and cell clumps was obtained. After 5-7 days of culture, colchicine was added. After another $4 \mathrm{~h}$, the short-term cultures were harvested according to standard protocols. The chromosomes in the dividing cells were G-banded and a karyotype established in accordance with the recommendations of the International System for Human Cytogenetic Nomenclature.

\section{Results}

Clinical data

All patients had stage IV disease (Table 1). Of particular interest is that four of them (patients 2, 3, 4 and 7) presented with predominant involvement of the GI tract.

\section{Morphology}

The architecture of the lymphoma infiltrates in the GI tract, bone marrow and lymph nodes was either diffuse, nodular or showed expanded mantle zones around germinal centres. All cases showed small- to medium-sized cells with round to slightly irregular nuclei, admixed with areas of slightly larger cells with more abundant clear cytoplasm giving the cells a monocytoid appearance (Fig. 1a, b and c). In the bone marrow, diffuse infiltration with small lymphoid cells, as well as an intrasinusoidal growth pattern, was observed in patients 1, 2 and 3. Case 2 showed two clones of cyclin D1-positive tumour cells: one immunoglobulin light-chain kappa expressing component composed of small cells with hyperchromatic and irregular nuclei and the other component made out of slightly bigger cells with more abundant cytoplasm and irregular nuclei with clumped chromatin that expressed immunoglobulin light-chain lambda.

Immunophenotype

Immunohistochemical analysis showed expression of B-cell markers, variable expression of CD5 and overexpression of cyclin D1 in all cases.

The flow cytometry analysis demonstrated CD5 positivity in two of four cases, of which one was also positive for $\mathrm{CD} 23$. The remaining two cases were CD5 and CD23 negative. The complete immunophenotypes are summarised in Table 2. Cyclin D1 expression is illustrated in Fig. 1d.

\section{Cytogenetics}

Karyotyping of G-banded chromosomes was attempted in four of the cases (Table 2). One showed the characteristic $\mathrm{t}(11 ; 14)$ with an additional +3 , two failed, and the last one

Fig. 1 a, b and $\mathbf{c} H \& E$ section of case 5 . The case shows a biphasic morphology with a dark and a clear zone. The clear zone contains cells with more abundant clear cytoplasm, reminiscent of marginal-zone lymphoma $(\times 20, \times 40$ and $\times 60$ magnification). d cyclin D1 expression by the tumour cells (case 5)
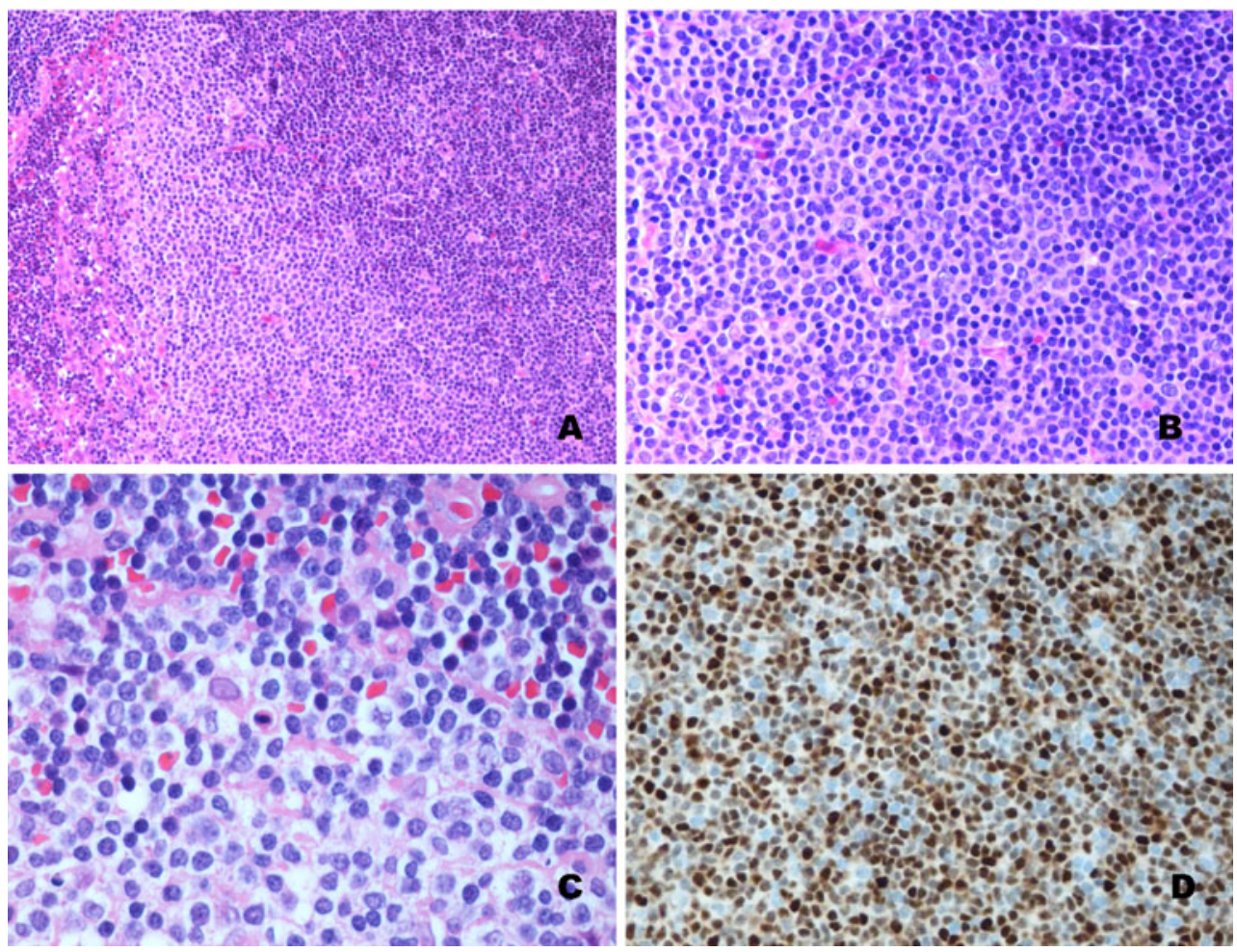
Table 2 Immunophenotypic and genetic features of the cases

\begin{tabular}{|c|c|c|c|c|c|c|}
\hline \multirow[t]{2}{*}{ Case } & \multirow[t]{2}{*}{ Immunohistochemistry } & \multirow[t]{2}{*}{ Flow cytometry } & \multirow{2}{*}{$\begin{array}{l}\text { Proliferation } \\
\text { index }^{\mathrm{a}}(\%)\end{array}$} & \multirow{2}{*}{$\begin{array}{l}\text { Molecular } \\
\text { pathology }\end{array}$} & \multicolumn{2}{|l|}{ Cytogenetics } \\
\hline & & & & & Karyotype & FISH \\
\hline 1 & $\begin{array}{l}\text { CD20+, Cyclin-D1+, } \\
\text { CD5-, CD23-, CD10- }\end{array}$ & $\begin{array}{l}\text { CD19+, CD20bright (b)+, CD22+, } \\
\text { CD24d+, FMC7+, CD5-/dim } \\
\text { (d)+, CD10-, CD23-, kappa }+\end{array}$ & 10 & $\begin{array}{l}96,5 \% \text { homology } \\
\text { to } \operatorname{IgH} \text { V4-b1 } \\
\text { gene }\end{array}$ & $46, \mathrm{XX}$ & $\mathrm{t}(11 ; 14)(\mathrm{q} 13 ; \mathrm{q} 32)$ \\
\hline 2 & $\begin{array}{l}\text { CD20+, Cyclin-D1+, } \\
\text { CD5-, CD23-, CD10- }\end{array}$ & $\begin{array}{l}\text { CD19+, CD20b+, CD22+, CD24+, } \\
\text { FMC7+, CD5-/d+, CD23-, } \\
\text { CD } 38+, \text { lambda }+(80 \% \text { of } \\
\text { lymphoma cells) kappa }+ \\
(20 \% \text { of lymphoma cells })\end{array}$ & 10 & $\begin{array}{l}100 \% \text { homology to } \\
\text { IgH V3-21 gene }\end{array}$ & $\begin{array}{l}47, \mathrm{XY},+3, \mathrm{t} \\
\quad(11 ; 14)(\mathrm{q} 13 ; \mathrm{q} 32)\end{array}$ & $\begin{array}{l}\mathrm{t}(11 ; 14)(\mathrm{q} 13 ; \mathrm{q} 32) \\
\quad \text { trisomy } 3\end{array}$ \\
\hline 3 & $\begin{array}{l}\text { CD20+, Cyclin-D1+, } \\
\text { CD5+, CD23-, CD10- }\end{array}$ & & 40 & $\begin{array}{l}\text { No material } \\
\text { available }\end{array}$ & Not performed & $\mathrm{t}(11 ; 14)(\mathrm{q} 13 ; \mathrm{q} 32)$ \\
\hline 4 & $\begin{array}{l}\mathrm{CD} 20+, \text { Cyclin-D1+, } \\
\text { CD5+, CD23-, CD10- }\end{array}$ & & $20-30$ & $\begin{array}{l}\text { No material } \\
\text { available }\end{array}$ & Not performed & $\mathrm{t}(11 ; 14)(\mathrm{q} 13 ; \mathrm{q} 32)$ \\
\hline 5 & $\begin{array}{l}\text { CD20+, Cyclin-D1+/-, } \\
\text { CD5+(weak), CD23-, } \\
\text { CD10- }\end{array}$ & $\begin{array}{l}\text { CD19+, CD20+, CD5+, CD10-, } \\
\text { CD23-, lambda+ }\end{array}$ & $10-20$ & $\begin{array}{l}100 \% \text { homology to } \\
\text { IgH V3-21 gene }\end{array}$ & Failed & $\mathrm{t}(11 ; 14)(\mathrm{q} 13 ; \mathrm{q} 32)$ \\
\hline 6 & $\begin{array}{l}\text { CD20+, Cyclin-D1+/-, } \\
\text { CD5+, CD23-, CD10- }\end{array}$ & $\begin{array}{l}\mathrm{CD} 19+, \mathrm{CD} 20 \mathrm{~b}+, \mathrm{CD} 22+, \mathrm{CD} 24+, \\
\mathrm{FMC} 7+, \mathrm{CD} 5+, \mathrm{CD} 10-, \mathrm{CD} 23+ \\
\text { CD38+, kappa+ }\end{array}$ & 10 & $\begin{array}{l}95,7 \% \text { homology } \\
\text { to } \operatorname{IgH~V} 3-7 \\
\text { gene }\end{array}$ & Failed & $\begin{array}{l}\mathrm{t}(11 ; 14)(\mathrm{q} 13 ; \mathrm{q} 32) \\
\quad \text { in } 13 \% \text { of cells }\end{array}$ \\
\hline 7 & $\begin{array}{l}\text { CD20+, Cyclin-D1+, } \\
\text { CD5+, CD23-, CD10- }\end{array}$ & & 10 & $\begin{array}{l}\text { No material } \\
\text { available }\end{array}$ & Not performed & $\mathrm{t}(11 ; 14)(\mathrm{q} 13 ; \mathrm{q} 32)$ \\
\hline
\end{tabular}

${ }^{\mathrm{a}}$ Estimated from Ki67 staining

showed a normal chromosomal pattern. However, FISH proved the presence of a $\mathrm{t}(11 ; 14)(\mathrm{q} 13 ; \mathrm{q} 32)$ in all seven cases. Trisomy 3 was proven by FISH in case 2, but not in any of the other six cases.

\section{Discussion}

Mantle cell lymphomas typically show a monotonous infiltration of small- to medium-sized cells with irregular nuclei without prominent nucleoli. We describe seven patients with mantle cell lymphoma that displays a biphasic histology resembling marginal-zone B-cell lymphoma. Besides typical mantle lymphoma cells, the cases showed distinct areas with larger, monocytoid cells. The latter feature is rare in mantle cell lymphoma and only 15 similar cases have previously been described. The first report was by Swerdlow et al. who described four similar cases [4]. Of interest, two of those cases also showed an intrasinusoidal growth pattern in the bone marrow, similar to three of our cases described here. Another case of mantle cell lymphoma with marginal-zone lymphoma features was described in a spleen specimen by Mollejo et al. [5]. This case exhibited features of splenic marginal-zone lymphoma, with a biphasic morphology as seen in our cases. However, the clear cells reminiscent of marginal-zone differentiation in this case seemed to also consist of large anaplastic cells that expressed p53, whereas p53 was absent in the smaller cells. The biphasic pattern in this case is likely related to transformation. The case described by Anagnostopoulos et al. presented in the tonsils and showed also prominent marginal-zone differentiation [6]. In contrast to our cases, the case did not show areas with typical mantle cell lymphoma. Of interest, the case showed even preserved normal mantle zones with the mantle cell lymphoma growing in the periphery and showing prominent monocytoid features. A similar case was described by Jacobson et al. albeit in an axillary lymph node [7]. The three cases described by Mansoor et al. shared the biphasic nature of the lymphoma as seen in our cases [8]. Another five cases have recently been described and have similar histological findings as the cases we describe here [9-11]. Interestingly, the cases described by D'Antonio et al. also presented in the GI tract [9].

In addition to the biphasic histology of our cases, a feature that has been described before, the cases shared other features with marginal-zone lymphoma, which are unusual for typical mantle cell lymphoma. Three of our cases showed a somewhat variant immunophenotype as the one typically associated with mantle cell lymphoma. Indeed, cases 1 and 2 were both negative for CD5. This was also seen in a case described by Mansoor et al. and in the one case of Golardi et al. [8, 11]. Our case 1 was also negative for $\mathrm{CD} 24$ and $\mathrm{CD} 38$, which is consistent with a marginal-zone lymphoma. In case 6 , that was positive for CD5 and CD23, a differential diagnosis with chronic lymphocytic leukaemia was considered. However, all cases showed expression of cyclin D1, and $\mathrm{t}(11 ; 14)(\mathrm{q} 13$; 
q32) was proven by FISH, allowing these cases to be confidently identified as mantle cell lymphomas.

Trisomy 3 was demonstrated in one of the lymphomas. This is a chromosomal abnormality often seen in marginalzone B-cell lymphoma; although trisomy 3 can be present in many non-Hodgkin lymphoma types and $3 \mathrm{q}$ gain is quite common also in typical mantle cell lymphoma [12-14]. The trisomy could not be demonstrated in any of our other cases. Somatic hypermutation of immunoglobulin heavy chain genes was detected in two of the four cases that could be analysed, a feature more often seen in marginal-zone lymphoma than in mantle cell lymphoma [15-17]. The case of mantle cell lymphoma with features of marginal-zone lymphoma reported by Anagnostopoulos et al. did not show somatic hypermutation of the rearranged immunoglobulin gene [6]. Somatic hypermutations have not been studied in the other reports of similar cases.

All of our patients presented with stage IV lymphoma, and two of the patients died shortly after diagnosis. Interestingly, four of the seven patients showed predominant affection of the GI tract and there was predominant spleen involvement in one of the patients. These disease localizations are more typical for marginal-zone lymphoma. Extranodal disease was also common in the previously described patients [4-6, 8, 9].

In conclusion, we report seven cases of mantle cell lymphoma with morphological and cytogenetic abnormalities that mimic marginal-zone lymphoma. Extensive extranodal disease seems to be more common in such cases, and the involvement of the GI tract is common.

Conflict of interest The authors have nothing to disclose.

\section{References}

1. Swerdlow SH, Campo E, Seto M et al (2008) Mantle cell lymphoma. In: Swerdlow SH, Campo E, Harris NL et al (eds) WHO classification of tumours of haematopoietic and lymphoid tissues. IARC, Lyon, pp 229-232

2. Dreyling M, Hiddemann W; European MCL Network (2009) Current treatment standards and emerging strategies in mantle cell lymphoma. Hematology Am Soc Hematol Educ Program 542551

3. Geisler CH, Kolstad A, Laurell A et al (2008) Long-term progression-free survival of mantle cell lymphoma after intensive front-line immunotherapy with in vivo-purged stem cell rescue: a nonrandomized phase 2 multicenter study by the Nordic Lymphoma Group. Blood 112:2687-2693

4. Swerdlow SH, Zuckerberg LR, Yang WI et al (1996) The morphologic spectrum of non-Hodgkin's lymphomas with BCL1/cyclin D1 gene rearrangements. Am J Surg Pathol 20:627-640

5. Mollejo M, Lloret E, Solares J et al (1999) Splenic involvement by blastic mantle cell lymphoma (large cell/anaplastic variant) mimicking splenic marginal zone lymphoma. Am J Hematol 62:242-246

6. Anagnostopoulos I, Foss HD, Hummel M et al (2001) Extranodal mantle cell lymphoma mimicking marginal zone cell lymphoma. Histopathology 39:561-565

7. Jacobson E, Burke P, Tindle BH (2005) Mantle cell lymphoma disguised as marginal zone lymphoma. Arch Pathol Lab Med 129:929-932

8. Mansoor A, Akbari M, Auer I et al (2007) Cyclin D1 and t (11;14)-positive B-cell neoplasms resembling marginal zone B-cell lymphoma: a morphological variant of mantle cell lymphoma. Hum Pathol 38:797-802

9. D'Antonio A, Boscaino A, Addesso M et al (2008) Nonpolypoid intestinal mantle cell lymphoma resembling MALT lymphoma with successful response to rituximab. South Med J 101:11681169

10. Schuetz MJ 3rd, Zafar N, Vasef MA (2009) Instances of mantle cell lymphoma morphologically mimicking other subtypes of B-cell lymphoid proliferation. South Med J 102:369373

11. Golardi N, Velasco MR, Elghetany MT (2009) Marginal zone variant of mantle cell lymphoma: CD5-negative cyclin D1positive variant posing a diagnostic dilemma. Pathol Int 59:317321

12. Salaverria I, Zettl A, Beà S et al (2007) Specific secondary genetic alterations in mantle cell lymphoma provide prognostic information independent of the gene expression-based proliferation signature. J Clin Oncol 25:1216-1222

13. Espinet B, Salaverria I, Beà $S$ et al (2010) Incidence and prognostic impact of secondary cytogenetic aberrations in a series of 145 patients with mantle cell lymphoma. Genes Chromosomes Cancer 49:439-451

14. Dierlamm J, Michaux L, Wlodarska I et al (1996) Trisomy 3 in marginal zone B-cell lymphoma: a study based on cytogenetic analysis and fluorescence in situ hybridization. Br J Haematol 93:242-249

15. Thorsélius M, Walsh S, Eriksson I et al (2002) Somatic hypermutation and $\mathrm{V}(\mathrm{H})$ gene usage in mantle cell lymphoma. Eur J Haematol 68:217-224, Erratum in: Eur J Haematol 2002 68:401

16. Camacho FI, Algara P, Rodríguez A et al (2003) Molecular heterogeneity in MCL defined by the use of specific $V_{H}$ genes and the frequency of somatic mutations. Blood 101:4042-4046

17. Tierens A, Delabie J, Pittaluga S et al (1998) Mutation analysis of the rearranged immunoglobulin heavy chain genes of marginal zone cell lymphomas indicates an origin from different marginal zone B lymphocyte subsets. Blood 91:2381-2386 